\title{
Effect of Seed Rate and Row Spacing on Yield and Yield Components of Upland Rice (Oryza sativa L.) in Metema, West Gondar, Ethiopia
}

\author{
Endalkachew Aklilu \\ Gondar Agricultural Research Center, Gondar, Ethiopia \\ Email address: \\ endalkaklilu12@gmail.com
}

\section{To cite this article:}

Endalkachew Aklilu. Effect of Seed Rate and Row Spacing on Yield and Yield Components of Upland Rice (Oryza sativa L.) in Metema, West Gondar, Ethiopia. American Journal of Agriculture and Forestry. Vol. 8, No. 4, 2020, pp. 112-125. doi: 10.11648/j.ajaf.20200804.14

Received: May 6, 2020; Accepted: June 8, 2020; Published: July 6, 2020

\begin{abstract}
Rice is among the most important commercial cereal crops that can be produced in North Gondar. However, its production is challenged by low yield mainly due to lack of appropriate agronomic practices and recommendations. Uses of appropriate seed rate and row spacing most importantly affect the productivity of rice. Therefore, a field experiment was conducted to investigate the effects of seed rate and row spacing on grain yield and yield components of upland rice. Factorial combinations of four seed rates $\left(60,80,100\right.$ and $\left.120 \mathrm{~kg} \mathrm{ha}^{-1}\right)$ and three levels of row spacing $(20,25$ and $30 \mathrm{~cm})$ were laid out in RCBD with three replications using NERICA- 4 rice variety. The combine interaction effect of seed rate and row spacing was highly significant $(\mathrm{P}<0.01)$ on days to heading, days to maturity, number of total tiller per meter row length, thousand seed weight and grain yield, and significant $(\mathrm{P}<0.05)$ on plant height. The highest thousand seed weight $(27.3 \mathrm{~g})$ was recorded at seeding rate $\left(80 \mathrm{~kg} \mathrm{ha}^{-1}\right.$ and grow spacing of $30 \mathrm{~cm}$ but the lowest $(17.1 \mathrm{~g})$ was recorded on seed rate of $120 \mathrm{~kg}$ ha ${ }^{-1}$ and row spacing of $25 \mathrm{~cm}$. The highest grain yield $\left(4148.8 \mathrm{~kg} \mathrm{ha}^{-1}\right)$ was obtained at interaction of $80 \mathrm{~kg}^{-1}$ seed rate and $20 \mathrm{~cm}$ row spacing. While the lowest grains yield $\left(1826.4 \mathrm{~kg} \mathrm{ha}^{-1}\right)$ was obtained from the combination of $60 \mathrm{~kg}$ ha ${ }^{-1} \mathrm{seed} \mathrm{rate} \mathrm{and} 30 \mathrm{~cm}$ row spacing. In conclusion, the results revealed that seed rate and row spacing increased grain yield of rice by positively affecting the important yield components of the rice. The result of economic analysis showed that the maximum net benefit was obtained at seed rate of $80 \mathrm{~kg} \mathrm{ha}^{-1}$ and row spacing of $20 \mathrm{~cm}$. Hence use of $80 \mathrm{~kg} \mathrm{ha}^{-1}$ and $20 \mathrm{~cm}$ is promising for upland rice variety production under the rain fed condition at Metema district and similar agro ecologies.
\end{abstract}

Keywords: Interaction, NERICA -4, Economic Analysis, Row Spacing, Seed Rate

\section{Introduction}

Rice (Oryza sativa L.) ranks second after wheat in the world cereals grain production. Rice is the World's most important crop and it is a staple food for more than half of the world population [32]. It is the world's leading food crop, cultivated over an area of about 161.53 million ha with a production of about 481.14 million metric tons [16]. This represents $29 \%$ of the total output of grain crops worldwide [16]. Most of the increase in production has come from expansion in the area harvested rather than from increases in yields [48]. It provides about $22 \%$ of the world's supply of calories and $17 \%$ of the proteins [53].

The major rice growing regions are found in Asia, Latin America and Africa. Food and Agriculture Organization of the United Nations (FAO) estimated that Chinese rice farmers had produced $27.98 \%$ of the world rice followed by India (20.54\%), Indonesia (9.44\%), Bangladesh (6.94\%), Vietnam (5.98\%), Thailand (5.18\%), Myanmar (4.12\%) and Philippines $(2.47 \%)$. It is a traditional stable food in West Africa and Madagascar and it is important food crop in East, Central, and Southern Africa [6].

Rice is one of the most important cereal crops cultivated in sub-Saharan Africa. Rice is grown in over $75 \%$ of the African countries with a total population of 800 million people. The utilization of rice is increasing and the inequity between domestic productions and consumption has been increasing in sub-Saharan Africa making the rice import growing from time to time [40]. About $80 \%$ of rice in Africa is produced by small scale farmers for their own utilization 
and local market [52]. Rice yields in Africa are generally low averaged about $1 \mathrm{t} \mathrm{ha}^{-1}$ in uplands, 1 to $2 \mathrm{t} \mathrm{ha}^{-1}$ in rain fed lowlands and 3 to $4 \mathrm{tha}^{-1}$ in the irrigated zones and a range of factors explain this low productivity [1].

The cultivation of rice in Ethiopia is of a recent history. Currently, however, its use as food and cash crop is well recognized. The country is characterized with immense potential for growing the crop. In 2007, the government of Ethiopia declared rice as a millennium crop which gave prominence to the crop in the national agricultural program as well as ensuring food security in the country.

Rice is among the most important cereals crops grown in different parts of Ethiopia as food crop. It is the second among cereals in terms of average national yield $\left(2.84 \mathrm{t} \mathrm{ha}^{-1}\right)$ next to maize (3.94 $\left.\mathrm{t} \mathrm{ha}^{-1}\right)$ [12]. The introduction and expansion of rice production in suitable agro ecologies, therefore, could be an option to achieve food security and self-sufficiency.

Ethiopia has immense potentials for growing the crop. The estimated potential of Ethiopia for upland rice production is 30 million hectare [13]. From this 3.7 million hectare of land are suitable for irrigation [13]. In 2016/17 and 2017/18 cropping season, rice was produced on $48,418.09$ ha and $53,106.79$ ha of land in the country with total production of $1,360,007.26$ quintals and 1,510,183.30 quintals respectively. Ethiopia is the only region in the world with the lowest yield in rice. Estimated yields for 2017/2018 were 2.84 tons $\mathrm{ha}^{-1}$. It is an important crop which covers $39,829.58$ ha of land with total production of $1,180,309.43$ in quintals in Amhara region. The productivity of rice in Amhara region is 2.96 tons $\mathrm{ha}^{-1}$ [12]. It could serve as alternative crop choice for production diversification in the area.

According to [27], a quarter of the size of the Metema and area is having Haplic Luvisols soils and about 22\% are Vertisols or soils with vertic properties. Many of the areas are also flat. Hence, seasonal water logging, especially during the heavy rainfall months, is so high and it is the main production problem in the study area. Such a condition is not conducive for the dominant commercial crops like sesame and cotton production in the area. Household income and food security of rural farmers could be affected by the decline in the production of such crops due to the water logging problem. On the contrary, rice has potential to grow in water logging conditions. Considering such potential agroecology; various researches, development and none governmental organizations put some effort to introduce and raise rice production in the area. Yet, farmers are still facing different problems like, lack of agronomic practices. Therefore, this entails a need for more comprehensive study which rigorously examines the rice agronomy practice in the study area.

Row spacing plays a significant role on growth, development, and yield of rice at its optimum level beside it provides scope to the plants for efficient utilization of solar radiation and nutrients [34]. Closer spacing hampers intercultural operations and as such more competition arises among the plants for nutrients and light. As a result, plant becomes weaker, thinner and consequently reduces yield. Under wider row spacing, farmers cannot get desired number of plant per area which also ultimately reduces yield. Therefore, proper manipulation of planting density may lead to increase the economic yield of rice [43].

Sufficient information regarding their optimum planting density of rice under the agro-climatic condition of Metema, have not been generated so far. Farmers in the area use do to blanket recommendation of seed rate and row spacing. A seed rate of $60-120 \mathrm{~kg} \mathrm{ha}^{-1}$ and row spacing of $20-25 \mathrm{~cm}$ has been recommended for rice production throughout the Amhara Region without considering specific soil types and agro-ecological characteristics. Therefore, it is necessary to get the appropriate seed rate and row spacing for increased rice production in Metema area.

General Objective

To evaluate the appropriate rice seed rate and row spacing for rice production in Metema area.

Specific Objectives

a) To assess the effect of seed rate on yield and yield components of upland rice.

b) To assess the effect of row spacing on yield and yield components of upland rice.

c) To investigate the interaction effects between seed rate and row spacing on productivity of upland rice.

\section{Materials and Methods}

\subsection{Description of the Study Area}

The experiment was conducted in the main cropping season, under rain-fed condition at Afetet 1 and Afete 2 of Metema district in North Gondar, Amhara Regional State from July 2, 2017 to October 16, 2017. The experimental location represents the lowland areas of major rice growing area of North Gondar. The experimental is located about $900 \mathrm{~km}$ North West of Addis Ababa, about 360km Bahir Dar town, North West of Amhara region and about $200 \mathrm{~km}$ West of Gondar town (Figure 1) and about $30 \mathrm{~km}$ of East of Sudan border. The latitude and longitude of the district is $12^{\circ} 47^{\prime \prime} 38^{\prime} \mathrm{N}$ and $36^{\circ} 23^{\prime \prime} 41^{\prime} \mathrm{E}$, respectively, and an elevation of $760 \mathrm{~m}$ above sea level. The experimental site receives high amount of rainfall and an average annual rainfall of $1030 \mathrm{~mm}$ with maximum and minimum temperatures of 40.0 and $15.0^{\circ} \mathrm{C}$, respectively [38]. Types of soils in the area where about a quarter of the size of the District is Haplic Luvisols and about 22\% are Vertisols or soils with vertic properties [27].

\subsection{Meteorological Data}

Meteorological data [38] was obtained from Ethiopian Meteorological Agency, at Bahir Dar Branch. Among meteorological data average annual rainfall (mm) from 19992009 E.C, mean minimum and maximum temperature $\left({ }^{\circ} \mathrm{C}\right)$ was used (Table 1). 
Table 1. Agro-ecological feature of the experimental site.

\begin{tabular}{|c|c|c|c|c|c|c|c|c|}
\hline \multirow{2}{*}{ Locations } & \multirow{2}{*}{ Zone } & \multirow{2}{*}{$\begin{array}{l}\text { Altitude } \\
\text { (m.a.s.l) }\end{array}$} & \multirow{2}{*}{$\begin{array}{l}\text { Average annual } \\
\text { rain fall }(\mathrm{mm})\end{array}$} & \multirow{2}{*}{ Soil type } & \multicolumn{2}{|c|}{ Geographical coordinates } & \multicolumn{2}{|c|}{ Average temperature $\left({ }^{\circ} \mathbf{C}\right)$} \\
\hline & & & & & Latitude & Longitude & MaxT $^{0}$. & $\operatorname{Min}^{\mathbf{0}}$ \\
\hline Metema & North Gondar & 760 & 1030 & Sand-loam & $12^{0} 47^{\prime \prime} 38^{\prime} \mathrm{N}$ & $36^{0} 23^{\prime \prime} 41^{\prime} \mathrm{E}$ & 40.0 & 15.0 \\
\hline
\end{tabular}

Source: National Meteorological Agency, Bihar Dar Meteorological Branch [38]

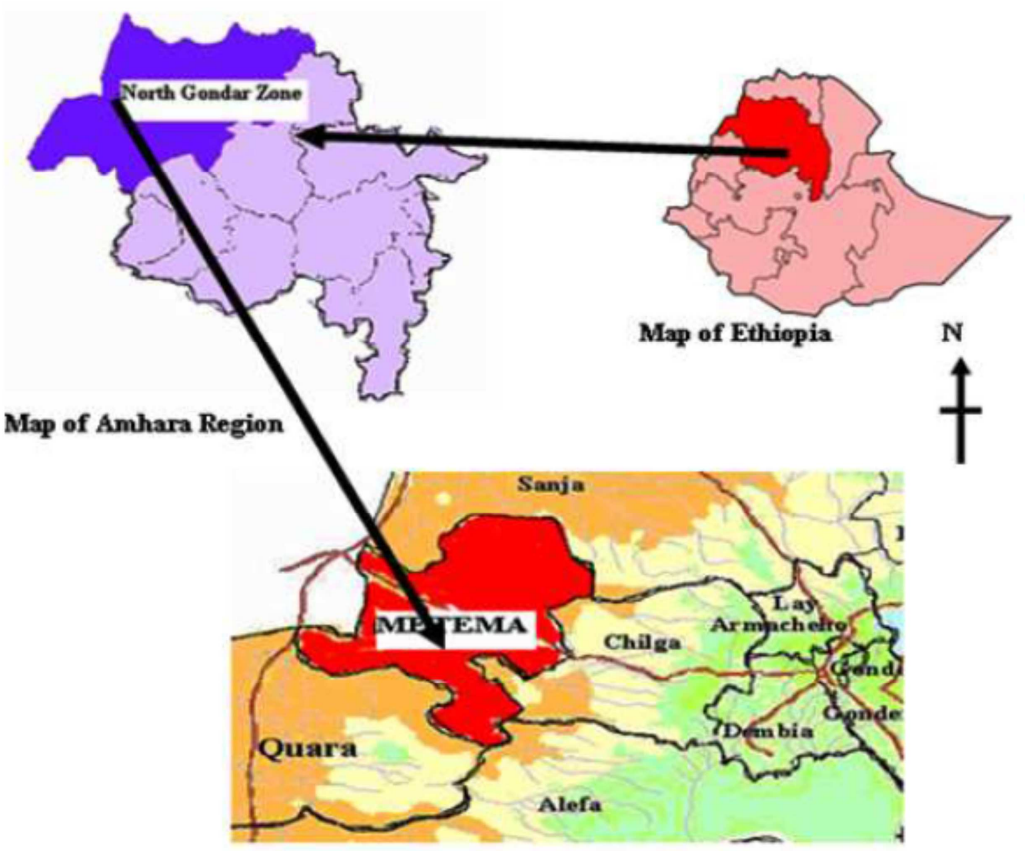

Figure 1. Location of the Study Site [27]

\subsection{Description of Experimental Materials}

Rice variety NERICA-4 was used for experiment. NERICA is used to refer to rice variety derived from the successful crossing of the two species of cultivated rice, the African rice (O. glaberrima S.) and the Asian rice (O. sativa L.), to produce progeny (known as interspecific) that combine the best traits of both parents [53]. NERICA 4 gave high yield potential and popularity among the farmers in study area. This cultivar is characterized by resistance to drought, pests and higher yields. It was recommended by Pawe Agricultural Research Center in 2006 for commercial cultivation mainly for warm areas. The key features of the variety are; panicle can hold up to 400 grains with a yield potential of 4.8 tons $\mathrm{ha}^{-1}$. It matures in 110 days.

\subsection{Treatments and Experimental Design}

The treatments comprised of factorial combinations of four seed rates $\left(60,80,100\right.$ and $\left.120 \mathrm{~kg} \mathrm{ha}^{-1}\right)$ and three row spacings $(20,25$ and $30 \mathrm{~cm})$. The experiment was laid out in factorial arrangement in a Randomized Complete Block Design (RCBD) with three replications. In accordance with specifications of the design, each treatment was assigned randomly to the plots within a block. The experimental plot had $2 \mathrm{~m}$ length and $3 \mathrm{~m}$ width with gross plot size of $6 \mathrm{~m}^{2}$. The distance between the plots and blocks were used at $0.5 \mathrm{~m}$ and $1 \mathrm{~m}$, respectively. There were 15,12 and 10 rows per plot as per treatments of 20,25, and $30 \mathrm{~cm}$ spacing respectively. Data were taken from the most central rows excluding a total of four rows ( 2 from the right and 2 from the left sides). A distance of $0.5 \mathrm{~m}$ from the top and $0.5 \mathrm{~m}$ from the bottom were excluded to avoid border effects. The net plot sizes for 20,25 , and $30 \mathrm{~cm}$ inter-row spacing were $2.2 \mathrm{~m}$ and $1.0 \mathrm{~m}, 2 \mathrm{~m}$ and $1.0 \mathrm{~m}$, and $1.8 \mathrm{~m}$ and $1.0 \mathrm{~m}$; respectively.

\subsection{Experimental Field Management}

To prepare a good seedbed for proper root penetration and development, the experimental field was ploughed three times with oxen and harrowing which were leveled by human. Seed was sown by drilling in rows of 20,25 and 30 $\mathrm{cm}$ apart. Planting was done on the first week of July, 2017 main cropping season, when there was adequate soil moisture in the field. The seed of variety was sown at a depth of 3- 5 $\mathrm{cm}$ to ensure adequate emergence.

All field activities (land preparation, planting, fertilizer application and weeding) were done as per recommended agronomic practices. Fertilizer was applied at the rate of 100 $\mathrm{kg} \mathrm{ha}^{-1}$ of NPS and $100 \mathrm{~kg} \mathrm{ha}^{-1}$ of Urea. All NPS and 1/3 Urea was applied at sowing while the rest urea was applied $1 / 3$ at tillering and $1 / 3$ at panicle initiation. All data on growth, yield and yield components were measured from the central net plot area of each plot. Manual wedding by hand was made three times. The first weeding was made at two weeks 
after sowing, the second at tillering stage and the third at flower initiation. The crop was harvested when the crop reached harvesting maturity.

\subsection{Data Collection}

\subsubsection{Phenological Parameters}

Days to $50 \%$ emergence was determined by counting the number of days from sowing to emergence and was determined by visual judgment and recorded when $50 \%$ of the expected population was emerged.

Days to $50 \%$ heading was determined by counting the number of days from planting to $50 \%$ of plants reach heading stage.

Days to $90 \%$ maturity was determined by counting the number of days from planting to $90 \%$ of plants reach maturity stage. At this stage the leaves started to senescence and panicle turned to yellow to golden brown in color.

\subsubsection{Growth Parameters}

Plant height was measured as the height from the soil surface to the top of the spike. It was recorded as the average of five randomly selected main tillers from each plot at physiological maturity.

Panicle length was measured from the node where the first panicle branch starts to the tip of the panicle as the average of five randomly taken panicles at harvesting.

\subsubsection{Yield and Yield Related Traits}

Number of tillers per meter row length was recorded from five places in the net plot area was recorded and expressed as average number of tillers per $1.0 \mathrm{~m}$ row length.

Number of filled grains per panicle was taken as the number of filled grains from the main panicle at harvest from average of five randomly taken plants.

Number of un-filled grains per panicle was the number of unfilled grains from the main panicle at harvest from average of five randomly taken plants.

Biomass yield including the straw and grain was harvested at the ground levels sundried and weighed.

Thousand grain weight was counted at random from each plot and their weights were taken sensitive balance and adjusted at $14 \%$ moisture content.

Grain yield $\left(\mathrm{t} \mathrm{ha}^{-1}\right)$ was recorded in $\mathrm{kg}$ fromeach net plot and adjusting at the standard 14\% moisture content.

Harvest index (HI) was calculated by dividing grain yield by total biomass yield multiplied by 100 from each plot.

$$
\mathrm{HI}=\frac{\mathrm{GY}}{\mathrm{TBY}} \times 100 \%
$$

Where: $\mathrm{GY}=$ Grain Yield, $\mathrm{TBY}=$ Total Biomass Yield, $\mathrm{HI}=$ Harvest Index.

\subsection{Data Analysis}

The data were subjected to analysis of variance by SAS software. Significance of differences between samples was separated using the least significance difference (LSD) at 5\% level of significance. Correlation analysis was also carried out to study the nature and degree of relationship between yield and yield components of upland rice. Correlation coefficient values (r) were calculated and test of significance was analyzed using Pearson correlation procedure found in SAS software.

The mean grain and straw yield data was adjusted down by $10 \%$ and subjected to partial budget and economic analysis was performed following the CIMMYT partial budget methodology [10]. Total costs that varied (seed and planting cost) for each treatments was calculated and treatments were ranked in order of ascending total variable cost (TVC) and dominance analysis was used to eliminate those treatments costing more but producing a lower net benefit than the next lowest cost treatment. The prices of the inputs that were prevailing at the time of their use were considered for working out the cost of cultivation. Net returns per hectare were calculated by deducting cost of production per hectare from gross income per hectare. A treatment which is nondominated and having the highest net benefit is said to be economically profitable [10].

\section{Results and Discussion}

\subsection{Phenological Parameters}

\subsubsection{Days to Emergence}

The combine analysis show that days to $50 \%$ crop emergence were not significantly affected by seed rate, row spacing and by their interaction (Table A1). On average, rice seedlings emerged within 9.78 to 11 days, regardless of seed rates and row spacings used. Favorable moisture condition due to adequate supply of rain fall during sowing time and well prepared seedbed might have contributed to smooth and even germination. In line with this result, [47] reported nonsignificant variation in days to emergence. [14] also reported non-significance difference in days to emergence rice with the use of 75,100 and $125 \mathrm{~kg} \mathrm{ha}^{-1}$ of seed rate.

\subsubsection{Days to Heading}

Analysis of variance showed that the combine main effect of seed rate had highly significant and row spacing had significant effect on days to heading. Similarly the interaction effect of seed rate and row spacing significantly affected the heading days (Table A1). The longest days to $50 \%$ heading (75.33) was recorded at seed rate of $60 \mathrm{~kg} \mathrm{ha}^{-1}$ at $25 \mathrm{~cm}$ row spacing, which had highly significant difference with $120 \mathrm{~kg}$ $\mathrm{ha}^{-1}$ at 25 and $30 \mathrm{~cm}$ while the shortest days to $50 \%$ heading (55.33) was recorded at seed rate of $120 \mathrm{~kg} \mathrm{ha}^{-1}$ by $20 \mathrm{~cm}$ of row spacing. This might be because with lower seed rates plant competition for growth resources was lesser than the competition at higher seed rates. The higher availability of nutrients and light resulted in more plant growth as compared to lower seed rates. The earliness to heading in highest seeding rate might be due to the higher competition to resources; this may help plants to escape terminal moisture stress (Table 2).

In line with this result, [14] observed earlier heading and flowering of rice from the highest seed rate of $125 \mathrm{~kg} \mathrm{ha}^{-1}$. 
The head to emergence was significantly delayed with the successive increase in row spacing. This might be due to reduced rate of photosynthesis because of the competition of plants for light, space, nutrients and water under closer spacing. [19] reported one day earlier head to emergence in plots with $20 \mathrm{~cm}$ than with $30 \mathrm{~cm}$ row spacing.

Table 2. The combine interaction effect of seed rate and row spacing on days to headingat two locations at Metema during 2017.

\begin{tabular}{llll}
\hline \multirow{2}{*}{ Seed rate $\left(\mathbf{k g h a}^{-1}\right)$} & \multicolumn{3}{l}{ Row spacing $(\mathbf{c m})$} \\
\cline { 2 - 4 } & $\mathbf{2 0}$ & $\mathbf{2 5}$ & $\mathbf{3 0}$ \\
\hline 60 & $74.00^{\mathrm{a}}$ & $75.33^{\mathrm{a}}$ & $75.00^{\mathrm{a}}$ \\
80 & $71.67^{\mathrm{a}}$ & $75.00^{\mathrm{a}}$ & $63.67^{\mathrm{cd}}$ \\
100 & $58^{\mathrm{e}}$ & $65.67^{\mathrm{bc}}$ & $71.00^{\mathrm{ab}}$ \\
120 & $56.33^{\mathrm{e}}$ & $57.33^{\mathrm{e}}$ & $58.30^{\mathrm{de}}$ \\
Mean & 66.72 & & \\
LSD (5\%) & 5.47 & & \\
CV (\%) & 4.86 & & \\
\hline
\end{tabular}

Means with the same letters are not significantly different at $5 \%$ level of significantly. LSD: Least Significant Difference at $5 \%$ level of significant; CV: coefficient of variation in percent

\subsubsection{Days to Physiological Maturity}

Analysis of variance showed that seed rate and row spacing had highly significant $(P<0.01)$ effect on days to $90 \%$ physiological maturity and their interaction was highly significant different (Table A1). The number of days taken to reach to $90 \%$ physiological maturity of rice plants decreased with the increase in seed rate. The longest days to $90 \%$ maturity (109) was recorded at interaction of $80 \mathrm{kgha}^{-1}$ seed rate and $30 \mathrm{~cm}$ row spacing, which had no significant difference with $\left(60 \mathrm{~kg} \mathrm{ha}^{-1}\right.$ and $\left.30 \mathrm{~cm}\right)$ and $\left(60 \mathrm{~kg} \mathrm{ha}^{-1}\right.$ and $25 \mathrm{~cm}$ ) seed rate and row spacing respectively, while the shortest days to $90 \%$ maturity (92) was recorded at $100 \mathrm{~kg}$ $\mathrm{ha}^{-1}$ seed rate and $25 \mathrm{~cm}$ row spacing, which had no significant difference with $\left(120 \mathrm{~kg} \mathrm{ha}^{-1}\right.$ and $\left.20 \mathrm{~cm}\right),(120 \mathrm{~kg}$ $\mathrm{ha}^{-1}$ and $\left.25 \mathrm{~cm}\right),\left(120 \mathrm{~kg} \mathrm{ha}^{-1}\right.$ and $\left.30 \mathrm{~cm}\right),\left(100 \mathrm{~kg} \mathrm{ha}^{-1}\right.$ and 20 $\mathrm{cm})$ and $\left(80 \mathrm{~kg} \mathrm{ha}^{-1}\right.$ and $\left.20 \mathrm{~cm}\right)$ seed rate and row spacing respectively, (Table 3 ).

The prolonged days to $90 \%$ maturity with lowest population density or wider inter row spacing might be due to less competition of light interception, high availability of growth resources, that promote luxurious growth; and enhanced the lateral growth. Early maturity with narrow spacing could be due to the presence of intense inter plant competition at the closer row spacing that might have led to depletion of the available nutrient which might have resulted in stress and might lead to early heading and maturity [39].

In conformity with this result, [44] observed earlier physiological maturity of rice (4 days) with the increment of seed rate from $60-120 \mathrm{~kg} \mathrm{ha}^{-1}$. [50] also confirmed that days to physiological maturity were earlier by 6 days when the seed rate was increased from 80 to $100 \mathrm{~kg} \mathrm{ha}^{-1}$. [55] also concluded that closer inter row spacing (increasing plants density) shortened days to physiological maturity in rice. This could be due to the presence of intense inter plant competition at the closer row spacing that might have led to the depletion of the available nutrient that results plants tend to mature earlier.

Table 3. The combine interaction effect of seed rates and row spacing on days to maturity at Metema (Afetet 1 and Afete 2) during 2017.

\begin{tabular}{llll}
\hline \multirow{2}{*}{ Seed rate $\left(\mathbf{k g ~ h a -}{ }^{\mathbf{1}}\right)$} & \multicolumn{4}{l}{ Row spacing $\mathbf{( c m )}$} & $\mathbf{3 0}$ \\
\cline { 2 - 4 } & $\mathbf{2 0}$ & $\mathbf{2 5}$ & $108^{\mathrm{a}}$ \\
\hline 60 & $102^{\mathrm{bc}}$ & $104^{\mathrm{b}}$ & $109^{\mathrm{a}}$ \\
80 & $95.30^{\mathrm{de}}$ & $92^{\mathrm{e}}$ & $102.667^{\mathrm{b}}$ \\
100 & $98.28^{\mathrm{cd}}$ & $93^{\mathrm{e}}$ & $95^{\mathrm{de}}$ \\
120 & $95.32^{\mathrm{de}}$ & & \\
Mean & 100.31 & & \\
LSD (5\%) & 3.99 & & \\
CV (\%) & 2.36 & \\
\hline
\end{tabular}

Means with the same letters are not significantly different at 5\% level of significantly. LSD: Least Significant Difference at 5\% level of significant, $\mathrm{CV}$ : coefficient of variation in percent

\subsection{Growth Parameters}

\subsubsection{Plant Height}

The results revealed that the height of the rice plant was highly significantly $(P<0.01)$ affected by seed rate and row spacing but their interaction effect was significant. The maximum plant height was recorded $(115.67 \mathrm{~cm})$ at seed rate of $120 \mathrm{~kg} \mathrm{ha}^{-1}$ and row spacing of $30 \mathrm{~cm}$, which had highly significant difference with other treatments while the minimum plant height $(81 \mathrm{~cm})$ was recorded at $60 \mathrm{~kg} \mathrm{ha}^{-1}$ and $20 \mathrm{~cm}$ of seed rate and row spacing respectively (Table 4). Although the interaction showed that plant height was statistically significant there was a gradual increase in plant height with increased seed rate (Table 4). Overcrowding due to increment of seeding rate per unit area might have resulted in aerial intra-specific competition between rice plants for light and space and promoted elongation of stem or tillers of rice.

In conformity with this result, [18] observed increasing trend in rice plant height as the level of seeding rate increased from 40 to $80 \mathrm{~kg} \mathrm{ha}^{-1}$. According to [55] row spacing of $30 \mathrm{~cm}$ resulted in significantly higher plant height $(104.98 \mathrm{~cm})$ than $20 \mathrm{~cm}$ and $25 \mathrm{~cm}$ row spacing. This increment in plant height at wider row spacing might be due to less competition of plants for nutrients, moisture, space and light providing better environment for growth and development of crop. In line to this result, [41] found plant heights $(79.85 \mathrm{~cm})$ in wider row spacing of $30 \mathrm{~cm}$ and the lower plant heights $(75.62 \mathrm{~cm})$ in $20 \mathrm{~cm}$ a part rows on wheat.

In contrast to this result, [31] and [30] reported that narrow spacing $(20 \mathrm{~cm})$ produced the tallest plants as compared to 30 $\mathrm{cm}$ inter-row spacing in rice. These results were in agreement with those reported by [21] and [2]. [2] reported the highest plant height was obtained in spacing of $25 \mathrm{~cm}$ in rice. Overcrowding due to increment of seed rate per unit area might have invited aerial intra-specific competition between rice plants for light and space and promoted elongation of stem/tillers to certain extent at the early stages of growth, while it may have depressed elongation of stem/tillers at the 
later period, resulting in shorter plants in response to a closer spacing as suggested by [30].

Table 4. Interaction effect of seed rate and row spacing on plant height at Afete 1 and Afetet 2 during 2017.

\begin{tabular}{llll}
\hline \multirow{2}{*}{ Seed rate $\left(\mathbf{k g ~ h a}^{-\mathbf{1}}\right)$} & \multicolumn{4}{l}{ Row spacing $(\mathbf{c m})$} & $\mathbf{3 0}$ \\
\cline { 2 - 4 } & $\mathbf{2 0}$ & $\mathbf{2 5}$ & $98.27^{\mathrm{d}}$ \\
\hline 60 & $81^{\mathrm{f}}$ & $89.267^{\mathrm{e}}$ & $100.667^{\mathrm{cd}}$ \\
80 & $99^{\mathrm{d}}$ & $97.87^{\mathrm{d}}$ & $109.73^{\mathrm{b}}$ \\
100 & $98^{\mathrm{d}}$ & $101.20^{\mathrm{cd}}$ & $115.67^{\mathrm{a}}$ \\
120 & $105.40^{\mathrm{bc}}$ & $103.47^{\mathrm{cd}}$ & \\
Mean & 100.02 & & \\
LSD (5\%) & 5.86 & & \\
CV (\%) & 3.48 & & \\
\hline
\end{tabular}

LSD $(0.05)=$ Least Significant Difference at $5 \%$ level; $\mathrm{CV}=$ coefficient of variation; Means followed by the same letter(s) are not significantly different at $5 \%$ level of significance

\subsubsection{Panicle Length}

Analysis of variance showed that highly significant $(P<0.01)$ difference on panicle length due to main effect of seed rate and non significance difference effect due to row spacing and the interaction of seed rate and row spacing. The longest panicle lengths $(25.36$ and $24.31 \mathrm{~cm})$ were recorded at seed rates of $80 \mathrm{~kg} \mathrm{ha}^{-1}$ and $100 \mathrm{~kg} \mathrm{ha}^{-1}$, respectively, which had significant difference with 60 and $120 \mathrm{~kg} \mathrm{ha}^{-1}$ while the shortest panicle length $(19.04 \mathrm{~cm})$ was recorded at $120 \mathrm{~kg} \mathrm{ha}^{-}$ ${ }^{1}$ seed rate (Table 5). In contrast this finding [50] reported that seed rate did not affect significantly panicle length.

[36] indicated that panicle length is genetically characteristics that are influenced significantly by planting density. [11] showed that panicle density significantly increased with increase of seeding densities, while filled spikelets per panicle were reduced significantly.

Table 5. The combine main effect of seed rates on panicle length, during 2017 cropping season.

\begin{tabular}{ll}
\hline Seed rate $\left(\mathrm{kg} \mathrm{ha}^{-\mathbf{1}}\right)$ & Panicle length $(\mathbf{c m})$ \\
\hline 60 & $20.38^{\mathrm{b}}$ \\
80 & $25.36^{\mathrm{a}}$ \\
100 & $24.31^{\mathrm{a}}$ \\
120 & $19.04^{\mathrm{b}}$ \\
Mean & 22.3 \\
LSD (5\%) & 1.71 \\
CV (\%) & 7.89 \\
\hline
\end{tabular}

Means followed by the same letters are not significantly different at $5 \%$ level of significantly; LSD: Least Significant Difference at 5\% level of significant; CV: coefficient of variation in percent

\subsection{Yield Components}

\subsubsection{Number of Total Tillers per 1 Meter Row Length}

The analysis of variance revealed that the combine main effect of seed rate and row spacing were highly significant $(\mathrm{P}<0.01)$ on the total tillers per $1 \mathrm{~m}$ row length and their interaction was highly significant (Table A2). Higher number of total tillers per meter row length (78.67) was obtained from $80 \mathrm{~kg} \mathrm{ha}^{-1}$ seed rate and $20 \mathrm{~cm}$ row spacing while the lowest number of total tillers per $1 \mathrm{~m}$ row length [43] was found at $120 \mathrm{~kg} \mathrm{ha}^{-1}$ of seed rate and $20 \mathrm{~cm}$ of row spacing at Metema site (Table 6). Although no undesirable effects were observed in this study due to the highest seed rate could be due to the fact that higher seed rates resulted in reduced number of tillers per plant. In general, the number of tillers per plant increased with the increase in row spacing.

In line with this result, [15] reported that the highest number of effective tillers obtained with $80 \mathrm{~kg} \mathrm{ha}^{-1}$ seed rate was about $68 \%$ higher than the lowest seed rate. Increasing seeding rate would also increase density which increases unhealthy seedlings with small panicles due to competition for resources, and increase susceptibility to pests and diseases [28]. [55] reported in the wider row spacing, the more vigorous plants, with particularly higher tillering ability might have produced more photosynthesis than the less vigorous plants with the closer spacing.

[42] reported that the effect of spacing was pronounced in number of effective tillers which might be due to more space and nutrients available for the individual plant under wider spacing produced more number of tillers. [37] also found that the highest number of effective tillers per hill was found with $30 \mathrm{~cm}$ row spacing in rice crop. In the wider row spacing, the more vigorous plants, with particularly higher tillering ability might have produced more photosynthesis than the less vigorous plants with the closer spacing. The result was in conformity with [46]; and [51] who reported the highest effective tillers at optimum spacing as compared to lower spacing.

Table 6. Interaction effect of seed rate and row spacing on number of total tillers per 1.0 mrow length.

\begin{tabular}{llll}
\hline \multirow{2}{*}{ Seed rate $\left(\mathbf{k g ~ h a}^{-\mathbf{1}}\right)$} & \multicolumn{4}{l}{ Row spacing $(\mathbf{c m})$} \\
\cline { 2 - 4 } & $\mathbf{2 0}$ & $\mathbf{2 5}$ & $\mathbf{3 0}$ \\
\hline 60 & $52.3^{\text {fgh }}$ & $70.3^{\text {abcd }}$ & $71.5^{\text {abcd }}$ \\
80 & $78.67^{\mathrm{a}}$ & $65.5^{\text {bcde }}$ & $76.5^{\text {a }}$ \\
100 & $60.7^{\text {defg }}$ & $49.83^{\text {gh }}$ & $73^{\text {abc }}$ \\
120 & $43^{\mathrm{h}}$ & $55.16^{\text {efg }}$ & $62.16^{\text {cdef }}$ \\
Mean & 63.22 & & \\
LSD (5\%) & 11.18 & & \\
CV (\%) & 10.49 & & \\
\hline
\end{tabular}

Means with the same letters are not significantly different at 5\% level of significantly; LSD: Least Significant Difference at 5\% level of significant; $\mathrm{CV}$ : coefficient of variation in percent

\subsubsection{Number of Filled Grain per Panicle}

The analysis of variance revealed that the main effect of seed rate was high significant $(P<0.01)$ and row spacing was significance $(P<0.05)$ difference on number of filled grain per panicle while their interaction was not significant (Table A2). The highest number of filled grain per panicle (122.3) was found at seed rate $80 \mathrm{~kg} \mathrm{ha}^{-1}$ while the lowest number of filled grain (77.47) was recorded at seed rate of $120 \mathrm{~kg} \mathrm{ha}^{-}$ ${ }^{1}$ due to high competition of water, nutrients and light (Table 7). The highest number of filled seed per panicle (106.38) was recorded on row spacing of $20 \mathrm{~cm}$, and it was statistically different to row spacing 25 and $30 \mathrm{~cm}$ (Table 7). 
[7] reported that the increased plant spacing considerably resulted in vigorous plant growth and caused a significant increase in number of filled kernels per panicle in rice. In contrast to the results obtained [29] observed highest number of filled grains spike ${ }^{-1}(31.05)$ from the seed rate of $140 \mathrm{~kg}$ $\mathrm{ha}^{-1}$ and the lowest (26.55) from the seed rate of $100 \mathrm{~kg} \mathrm{ha}$. This result in contrast with [33] was obtained there was no significance of difference between 20,25 and $30 \mathrm{~cm}$.

Table 7. The combine main effect of seed rates and row spacing on number of filled grain per panicle of rice.

\begin{tabular}{ll}
\hline Seed rate $\left(\mathrm{kg} \mathrm{ha}^{-1}\right)$ & Number of filled grain per panicle \\
\hline 60 & $81.64 \mathrm{c}$ \\
80 & $122.8 \mathrm{a}$ \\
100 & $109.31 \mathrm{~b}$ \\
120 & $77.47 \mathrm{c}$ \\
LSD $(5 \%)$ & 12.54 \\
Row spacing $(\mathrm{cm})$ & \\
20 & $106.38 \mathrm{a}$ \\
25 & $94.63 \mathrm{~b}$ \\
30 & $92.40 \mathrm{~b}$ \\
Mean & 97.81 \\
LSD $(5 \%)$ & 10.857 \\
CV $(\%)$ & 13.18 \\
\hline
\end{tabular}

Means with the same letters are not significantly different at 5\% level of significantly; LSD: Least Significant Difference at 5\% level of significant; $\mathrm{CV}$ : coefficient of variation in percent

\subsubsection{Number of Unfilled Grain per Panicle}

Analysis of variance showed non significant $(P<0.01)$ difference due to main effect of seed rate and row spacing on un-filled grain per panicle and their interactions did not show significant different. The lowest number (5.8) of un-filled grain per panicle was recorded for the row spacing of $25 \mathrm{~cm}$ whereas the highest number (6.32) was recorded on row spacing of $20 \mathrm{~cm}$, but it was no statistically different to row spacing 25 and $30 \mathrm{~cm}$. This result was in contrast with the finding of [33] who reported that lowest number (1.93) of unfilled grain per panicle was obtained for the row spacing of $20 \mathrm{~cm}$.

\subsubsection{Biomass Yield}

The combine analysis of variance revealed that the main effect of seed rate was highly significant $(P<0.01)$ on biomass yield and row spacing was not significance $(P<0.05)$ different on biomass yield while their interaction not significant (Table A2). The highest biomass yield $(8568 \mathrm{~kg}$ $\mathrm{ha}^{-1}$ ) was obtained at $120 \mathrm{~kg} \mathrm{ha}^{-1}$ seed rate. However; this was statistically in parity with seed rate of $100 \mathrm{~kg} \mathrm{ha}^{-1}$. While the lowest biomass yield $\left(5710 \mathrm{~kg} \mathrm{ha}^{-1}\right)$ were obtained at 60 $\mathrm{kg} \mathrm{ha}^{-1}$ seed rate. In general, biomasses yield increase with the increasing seed rate. There was an increase of $36 \%$ in biomass yield with the application of $120 \mathrm{~kg}$ seed rate ha ${ }^{1}$ over $60 \mathrm{~kg}$ seed rate $\mathrm{ha}^{-1}$ (Table 8 ). The increase in biomass yield in response to application of seed rate might be due to its enhanced availability, uptake and induction of vigorous vegetative growth with more leaf area resulting in higher photosynthesis and assimilates that resulted in more dry matter accumulation [8].

Seed rate $\left(80 \mathrm{~kg} \mathrm{ha}^{-1}\right)$ attained higher plant height (Table 4), thousand seed weight (Table 10) and produced more tillers (Table 6) which promoted vegetative growth as well as development of the plants than their lower rates. The total dry matter per unit area was increased with an increase in spacing. This, in other way, implied that higher planting density within limit might produce more total dry matter per unit area which agrees with the results of this study.

The result was similar with to [4] found that increased biomass yield with wider row spacing due to higher production of tillers in rice. However, [9] reported that narrower row spacing produced higher biomass yield than wider row spacing in rice. In contrasting with this finding [45] also observed a significant increase in rice straw yield with seed rate up to $40 \mathrm{~kg} \mathrm{ha}^{-1}$.

Table 8. The combine main effect of seed rates on biomass yield of NERICA4 rice.

\begin{tabular}{ll}
\hline Seed rate $\left(\mathrm{kg} \mathrm{ha}^{-\mathbf{1}}\right)$ & Above ground biomass yield $\left(\mathbf{t ~ h a}^{\mathbf{- 1}}\right)$ \\
\hline 60 & $5.71^{\mathrm{c}}$ \\
80 & $7.1^{\mathrm{b}}$ \\
100 & $7.8^{\mathrm{a}}$ \\
120 & $8.1^{\mathrm{a}}$ \\
Mean & 7.2 \\
LSD (5\%) & 0.44 \\
CV (\%) & 6.25 \\
\hline
\end{tabular}

Means with the same letters are not significantly different at 5\% level of significantly; LSD: Least Significant Difference at 5\% level of significant; $\mathrm{CV}$ : coefficient of variation in percent

\subsubsection{Straw Yield}

The combine main effects of seed rate and row spacing were highly significant $(P<0.01)$ on straw yield of rice but their interaction was not significant. The highest straw yield $\left(5801 \mathrm{~kg} \mathrm{ha}^{-1}\right)$ was recorded at seed rate of $120 \mathrm{~kg} \mathrm{ha}^{-1}$ respectively, which had significant difference with 60 and 80 $\mathrm{kg} \mathrm{ha}^{-1}$ while the lowest straw yield (3320.4 $\mathrm{kg} \mathrm{ha}^{-1}$ ) was obtained at $80 \mathrm{~kg} \mathrm{ha}^{-1}$ seed rate (Table 9). It was also observed that increasing seed rates under in further increase in straw yield. In line with this result, [44] and [35] have shown rise in plant straw and biological yield to increase in seed rates. This result is in harmony with [3] and [54] who exhibited that as seeding rate increased, correspondingly straw yield increased due to higher stand number at crop establishment period.

On the other hand, row spacing highly significantly affected straw yield. The significantly maximum $(4677.1 \mathrm{~kg}$ $\mathrm{ha}^{-1}$ ) and minimum (3965.8 $\mathrm{kg} \mathrm{ha}^{-1}$ ) straw yield were observed for row spacing of 30 and $20 \mathrm{~cm}$, respectively. The highest straw yield $\left(4677.10 \mathrm{~kg} \mathrm{ha}^{-1}\right)$ obtained at the influence of widest row spacing $(30 \mathrm{~cm})$ was 15.2 and $15.98 \%$ more than the straw yield obtained with $20 \mathrm{~cm}$ and $25 \mathrm{~cm}$ row spacing, respectively. Row spacing might have influenced vegetative growth in terms of plant height and number of tillers per plant which resulted in increased straw 
yield (Table 9). Similar trend of straw yield was also reported by [21] who reported the highest straw yield was obtained in $30 \mathrm{~cm}$ row spacing in rice. In contrast with this [49] reported the higher straw yield was obtained in $20 \mathrm{~cm}$ row spacing in rice.

Table 9. The main effect of seed rates and row spacing on straw yield of rice.

\begin{tabular}{ll}
\hline Seed rate $\left(\mathbf{k g ~ h a}^{-1}\right)$ & Straw Yield $\left(\mathbf{t ~ h a}^{-1}\right)$ \\
\hline 60 & $3.4^{\mathrm{c}}$ \\
80 & $3.3^{\mathrm{c}}$ \\
100 & $4.3^{\mathrm{b}}$ \\
120 & $5.8^{\mathrm{a}}$ \\
LSD $(5 \%)$ & 0.45 \\
Row spacing $(\mathrm{cm})$ & \\
20 & $4.05^{\mathrm{b}}$ \\
25 & $4.02^{\mathrm{b}}$ \\
30 & $048^{\mathrm{a}}$ \\
Mean & 0.42 \\
LSD $(5 \%)$ & 0.39 \\
CV $(\%)$ & 10.93 \\
\hline
\end{tabular}

Means with the same letters are not significantly differentat $5 \%$ level of significantly; LSD: Least Significant Difference at 5\% level of significant; $\mathrm{CV}$ : coefficient of variation in percent

\subsubsection{Thousand Seed Weight}

Results from the analysis of variance indicated that both the main and their interaction effect of seed rate and row spacing were highly significant $(P<0.01)$ on thousand seed weight at Metema. Highest thousand seed weight $(27.3 \mathrm{~g})$ was obtained from $80 \mathrm{~kg} \mathrm{ha}^{-1}$ of seed rate and $30 \mathrm{~cm}$ of row spacing while the lowest thousand seed weight $(17.1 \mathrm{~g})$ was found at $120 \mathrm{~kg} \mathrm{ha}^{-1}$ and $25 \mathrm{~cm}$ of seed rate and row spacing, respectively (Table 10). The highest thousand grain weight at widest spacing might be due to efficient utilization of water, nutrients and light with minimal inter rows competition. On the other hand, at highest density competition would increase and little photosynthesis would be available to grain filling and finally thousand seed weight would reduce as result of insufficient photosynthesis during grain filling stage in densely populated crops. This result in line with [15] reported that increased row spacing, thousand seed weight also increase where the highest thousand seed weight $(23.97 \mathrm{~g})$ was recorded at row spacing of $30 \mathrm{~cm}$ while the lowest $(21.97 \mathrm{~g})$ was recorded at row spacing of $20 \mathrm{~cm}$.

The results showed that with the increase in row spacing the thousand seed weight also increased significantly. More number of grains per spike and higher 1000 -grain weight noted in wider rows $(25 \mathrm{~cm})$ might be due to efficient utilization of water, nutrients and light due to minimal inter-rows competition and lower plant population in rice [26]. In line with this result, [2] reported the highest thousand grain weight $(26.40 \mathrm{~g})$ in wider spacing of $30 \mathrm{~cm}$ inter-row spacing than closer spacing of $20 \mathrm{~cm}$ inter-row.

Likewise, [5] reported that wider row spacing $(22.5 \mathrm{~cm})$ produced more 1000-grains weight as compared to narrow row spacing $(11.25 \mathrm{~cm})$ in wheat. In this result it might be due to the interaction effect of seed rate and row spacing produced this variation of weight difference on thousand seed weight. In contrast with the result on the effect of seed rate on 1000 kernel weight, [44] reported that seeding rate of 60 to $120 \mathrm{~kg} \mathrm{ha}^{-1}$ was not significant in affecting thousand grain weight but showed a tendency to increase with increase of seed rates. [14] observed similar result but there was a decreasing trend in thousand grain weight as the seeding rate was increased from 75 to $125 \mathrm{~kg} \mathrm{ha}^{-1}$. This may be due to the fact that increased seed rate induce competition for assimilate

Table 10. The combine interaction effect of seed rate and row spacing on thousand seed weight of NERICA - 4 rice variety at Metema during 2017.

\begin{tabular}{llll}
\hline \multirow{2}{*}{ Seed rate $\left(\mathbf{k g ~ h a}^{-1}\right)$} & \multicolumn{4}{l}{ Row spacing $(\mathbf{c m})$} \\
\cline { 2 - 4 } & $\mathbf{2 0}$ & $\mathbf{2 5}$ & $\mathbf{3 0}$ \\
\hline 60 & $21.53^{\mathrm{e}}$ & $27^{\mathrm{ab}}$ & $23.13^{\mathrm{cde}}$ \\
80 & $25.53^{\mathrm{abc}}$ & $24.73^{\mathrm{abcd}}$ & $27.3^{\mathrm{a}}$ \\
100 & $22.13^{\mathrm{de}}$ & $22.067^{\mathrm{de}}$ & $24.467^{\mathrm{bcd}}$ \\
120 & $18.467^{\mathrm{fg}}$ & $17.1^{\mathrm{g}}$ & $20.933^{\mathrm{ef}}$ \\
& & & \\
Mean & 22.87 & & \\
LSD (5\%) & 2.73 & & \\
CV (\%) & 7.1 & & \\
\hline
\end{tabular}

Means with the same letters are not significantly different at 5\% level of significantly; LSD: Least Significant Difference at 5\% level of significant; $\mathrm{CV}$ : coefficient of variation in percent

\subsubsection{Grain Yield $\left(\mathrm{kg} \mathrm{ha}^{-1}\right)$}

The combine interaction effects of seed rate and row spacing as well as their interaction were highly significant $(P<0.01)$ on grain yield of rice. The highest grain yield $\left(4148.8 \mathrm{~kg} \mathrm{ha}^{-1}\right)$ was obtained at interaction of $80 \mathrm{~kg} \mathrm{ha}^{-1}$ of seed rate and $20 \mathrm{~cm}$ of row spacing while the lowest grain yields $\left(1826.4 \mathrm{~kg} \mathrm{ha}^{-1}\right)$ was obtained at interaction of $\left(60 \mathrm{~kg} \mathrm{ha}^{-1}\right.$ and $\left.30 \mathrm{~cm}\right)$ of seed rate and row spacing, respectively (Table 11). The result of this study was in line with that of [15] reported that highest grain yield obtained with the use of $80 \mathrm{~kg} \mathrm{ha}^{-1}$ seed rate was statistically greater than the other rates. The highest grain yield $\left(4148.8 \mathrm{~kg} \mathrm{ha}^{-1}\right)$ obtained with seed rate of $80 \mathrm{~kg} \mathrm{ha}^{-1}$ and row spacing $20 \mathrm{~cm}$ was 27,46 and $55 \%$ higher than that of $100 \mathrm{~kg} \mathrm{ha}^{-1}$ and $30 \mathrm{~cm}, 120 \mathrm{~kg} \mathrm{ha}^{-1}$ and $30 \mathrm{~cm}$ and $60 \mathrm{~kg}$ $\mathrm{ha}^{-1}$ and $30 \mathrm{~cm}$ of seed rate and row spacing, respectively. The lower plant population might have effectively utilized resources to give more grain yield. The numbers of effective tillers per meter row length, number of fill grain per panicle and thousand grain weights were the determinants of final yield.

Use of optimum seed rate is an important factor for maximizing yield of crops [24]. If more seed rate is used, plant population will be more and there will be competition among plants for water, nutrients, space and sunlight resulting in low quality and low yield. If less seed rate is used yield will be less due to lesser number of plants unit area $^{-1}$ [22]. In agreement with this result, [2] reported that the number of tillers per unit area is the most 
important component of yield. Therefore, the higher the number of tillers, especially fertile tillers, the more will be the yield.

In line with this result, [25] obtained that grain yield increases linearly with plant density until some competitive effects become apparent. Maximum rice grain yield ha $^{-1}$ was recorded at the seeding rate of $143.5 \mathrm{~kg} \mathrm{ha}^{-1}$ but a further increase in seed rate to 184.5 and $205 \mathrm{~kg} \mathrm{ha}^{-1}$ reduced yield to 5560 and $5150 \mathrm{~kg} \mathrm{ha}^{-1}$ [23]. [3] observed increase grain yield of rice with increased seed rates up to $143 \mathrm{~kg} \mathrm{ha}^{-1}$. In this study, the highest seed rate $80 \mathrm{~kg} \mathrm{ha}^{-1}$ at $20 \mathrm{~cm}$ row spacing used gave statistically higher yield to that of the other seed rates. The lower plant population might have effectively utilized the water, nutrients and light. [20] reported that closer spacing $(15 \mathrm{~cm})$ proved better in grain yield of rice was better than the wider row spacing. Similarly [17] reported that yield of cereals increased in response to decreasing the spacing between rows.

Table 11. The combine interaction effect of seed rates and row spacing ongrain yield of NERICA-4 rice variety at Metema during 2017 cropping main season.

\begin{tabular}{llll}
\hline \multirow{2}{*}{ Seed rate $\left(\mathbf{k g ~ h a}^{-1}\right)$} & \multicolumn{4}{l}{ Row spacing $(\mathbf{c m})$} & $\mathbf{3 0}$ \\
\cline { 2 - 4 } & $\mathbf{2 0}$ & $\mathbf{2 5}$ & $1826.4^{\mathrm{e}}$ \\
\hline 60 & $2469.8^{\mathrm{d}}$ & $2677.8^{\mathrm{cd}}$ & $3659.9^{\mathrm{b}}$ \\
80 & $4148.8^{\mathrm{a}}$ & $3520.1^{\mathrm{b}}$ & $3049.4^{\mathrm{c}}$ \\
100 & $3864.3^{\mathrm{ab}}$ & $3673.1^{\mathrm{b}}$ & $2294.2^{\mathrm{d}}$ \\
120 & $2313.7^{\mathrm{d}}$ & $2317.6^{\mathrm{d}}$ & \\
Mean & 2984.59 & & \\
LSD (5\%) & 389.34 & & \\
CV (\%) & 7.74 & & \\
\hline
\end{tabular}

Means with the same letters are not significantly different at $5 \%$ level of significantly; LSD: Least Significant Difference at 5\% level of significant; $\mathrm{CV}$ : coefficient of variation in percent

\subsubsection{Harvest Index}

The effect of seed rate and row spacing on harvest index was highly significant but their interaction was non significant difference. The highest harvest index (53.58) was recorded at seed rate of $80 \mathrm{~kg} \mathrm{ha}^{-1}$. While the lowest harvest index (28.49) was recorded at $120 \mathrm{~kg} \mathrm{ha}^{-1}$ seed rate (Table 12). In contrast with this result, [15] reported not significant effect of seed rate on harvest index of rice.

Similarly the highest harvest index [45] was obtained at narrow row spacing of $(20 \mathrm{~cm})$, which had no significance difference with $25 \mathrm{~cm}$ while the lowest harvest index (36.8) was obtained at $30 \mathrm{~cm}$ row spacing. Decreasing row spacing showed increased the harvest index (Table 12). Similarly, [37] who found that the highest harvest index was observed in $20 \mathrm{~cm}$ row spacing in rice crop, but statistically similar with $25 \mathrm{~cm}$ row spacing. [26] who found that higher harvest index was reported in $20 \mathrm{~cm}$ row spacing, but statistically similar with $25 \mathrm{~cm}$ row spacing in wheat crop. [49] reported the highest harvest index was obtained in $25 \mathrm{~cm}$ row spacing in rice. In contrast with [31]; and [5] in their respective studies obtained higher harvest index with the increasing row spacing in rice crop.

Table 12. The combine main effect of seed rates and row spacing on harvest index of NERICA-4 rice variety.

\begin{tabular}{ll}
\hline Seed rate $\left(\mathbf{k g ~ h a}^{-1}\right)$ & Harvest index \\
\hline 60 & $40.71^{\mathrm{c}}$ \\
80 & $53.58^{\mathrm{a}}$ \\
100 & $45.55^{\mathrm{b}}$ \\
120 & $28.49^{\mathrm{d}}$ \\
LSD $(5 \%)$ & 4.08 \\
Row spacing $(\mathrm{cm})$ & \\
20 & $45.00^{\mathrm{a}}$ \\
25 & $44.45^{\mathrm{a}}$ \\
30 & $36.89^{\mathrm{b}}$ \\
Mean & 42.08 \\
LSD $(5 \%)$ & 3.53 \\
CV $(\%)$ & 9.97 \\
\hline
\end{tabular}

Means with the same letters are not significantly different at $5 \%$ level of probability; LSD: Least Significant Difference at 5\% level of significant; $\mathrm{CV}$ : coefficient of variation in percent

\subsection{Correlations of Grain Yield and Yield Related Traits}

Knowledge of association between yield and its components is useful to make simultaneous selection for more than one character. The correlation analysis helps in determining the direction and number of characters to be considered in improving the yield. Correlations among the characters are presented in Table 13. Grain yield per hectare had high and positive associations with panicle length $(\mathrm{r}=$ $\left.0.77^{* *}\right)$, thousand seed weight $\left(\mathrm{r}=0.45^{* *}\right)$ and harvest index $(r=0.84 * *)$. This result indicated that agronomic traits like number of panicle length and harvest index could be exploited to increasing yield parameters in rice. This means with increasing value of these parameters, grain yield increases as well and vice versa. Besides this, there was non-significant and positive correlation with days to heading $(\mathrm{r}=0.048)$, total number of tiller per $1 \mathrm{~m}$ row length $(\mathrm{r}=0.18)$ and biomass yield $(\mathrm{r}=0.25)$. Whereas, there were negative correlations indicated among grain yield with days to maturity $(\mathrm{r}=-0.12)$ and plant height $(\mathrm{r}=-0.04)$ of upland rice.

Similarly dry biomass yield showed a negatively and highly significant correlation with days to heading $\left(\mathrm{r}=-0.68^{* *}\right)$ and days to maturity $\left(\mathrm{r}=-0.57^{* *}\right)$ but positively and highly correlation with plant height $(\mathrm{r}=0.72 * *)$ (Table 13). Harvest index showed a positive and highly significant correlation with panicle length $\left(\mathrm{r}=0.69^{* *}\right)$ and thousand seed weight $\left(\mathrm{r}=0.58^{* *}\right)$ (Table 13) while harvest index a positive and significant correlation with days to heading $\left(r=0.41^{*}\right)$. Likewise thousand seed weight exhibit a positive and highly significant correlation with days to heading $\left(\mathrm{r}=59^{* *}\right)$, days to maturity $\left(\mathrm{r}=0.69^{* *}\right)$, panicle length $\left(\mathrm{r}=0.49^{* *}\right)$ and total number of tiller per meter row length $\left(\mathrm{r}=0.48^{* *}\right)$ (Table 13). Number of total tiller per meter row length showed a positively and significant correlation on days to maturity $\left(\mathrm{r}=0.48^{*}\right)$ (Table 13 ). 
Table 13. Correlation among yield and yield components and growth parameters in response to seed rate and row spacing of rice.

\begin{tabular}{|c|c|c|c|c|c|c|c|c|c|}
\hline & DH & DM & PH & PL & TN & BY & TSW & HI & GY \\
\hline $\mathrm{DH}$ & 1 & & & & & & & & \\
\hline DM & $0.55^{* *}$ & 1 & & & & & & & \\
\hline $\mathrm{PH}$ & $-0.54^{* *}$ & $-0.37^{*}$ & 1 & & & & & & \\
\hline PL & $0.23^{\mathrm{ns}}$ & $0.03^{\mathrm{ns}}$ & $0.03^{\mathrm{ns}}$ & 1 & & & & & \\
\hline $\mathrm{TN}$ & $0.33^{\mathrm{ns}}$ & $0.45^{* *}$ & $0.09^{\mathrm{ns}}$ & $0.33^{\mathrm{ns}}$ & 1 & & & & \\
\hline BY & $-0.68^{* *}$ & $-0.57 * *$ & $0.72 * *$ & $0.09^{\mathrm{ns}}$ & $-0.13^{\mathrm{ns}}$ & 1 & & & \\
\hline TSW & $0.59 * *$ & $0.61 * *$ & $-0.26 \mathrm{~ns}$ & $0.49^{* *}$ & $0.48 * *$ & $-0.28^{\mathrm{ns}}$ & 1 & & \\
\hline HI & $0.41^{*}$ & $0.17^{\mathrm{ns}}$ & $-0.43^{* *}$ & $0.69^{* *}$ & $0.22^{\mathrm{ns}}$ & $-0.31^{\mathrm{ns}}$ & $0.58^{* *}$ & 1 & \\
\hline GY & $0.048^{\mathrm{ns}}$ & $-0.12^{\mathrm{ns}}$ & $-0.04^{\mathrm{ns}}$ & $0.77^{* *}$ & $0.18^{\mathrm{ns}}$ & $0.25^{\mathrm{ns}}$ & $0.45^{* *}$ & $0.84^{* *}$ & 1 \\
\hline
\end{tabular}

DH=days to $50 \%$ heading; $D M=$ days to $90 \%$ physiological maturity; $P H=$ plant height; $P L=$ panicle length; $T N=$ tiller numbers; TSW=thousand seed weight; $B Y=$ biomass yield; $H I=$ harvest index; $G Y=$ grain yield.

\subsection{Partial Budget Analysis}

In the result of present study, the costs for the different seeding rates, labor cost for rowmaking, drilling the seed and fertilizer application varied according to their rates and spacings requirements being other costs were constant for each treatment. In order to recommend the present result for the study area, it is necessary to estimate the minimum rate of return acceptable to producers in the recommendation domain. Based on partial budget analysis, the highest net benefit $\left(39,949.35\right.$ Birr ha $\left.^{-1}\right)$ was obtained from treatment combination of $80 \mathrm{~kg} \mathrm{ha}^{-1}$ seeding rate with $20 \mathrm{~cm}$ inter-row spacing with an acceptable MRR was obtained (Table 14). While the lowest net benefit $\left(17,312.78\right.$ Birr ha $\left.^{-1}\right)$ was obtained from the combination of $60 \mathrm{~kg} \mathrm{ha}^{-1}$ seeding rate with $30 \mathrm{~cm}$ row spacing with only in one growing season (Table 14). Farmers may have the opportunity to decrease seed and labor cost and to increase rice yield and ultimately improve their livelihoods through adopting the appropriate management practices.

According to (10), the minimum acceptable marginal rate of return (MRR\%) should be $100 \%$. The most attractive rates for small scale farmers of the study area with low cost of production and higher benefits in this case were $80 \mathrm{~kg} \mathrm{ha}^{-1}$ seeding rate and $20 \mathrm{~cm}$ row spacing combination also profitable with the highest net benefit and recommended.

Table 14. Results of the economic analysis for seed rate and row spacing of rice in Metema.

\begin{tabular}{|c|c|c|c|c|}
\hline Treatments & Total Variable Cost (Birr/ha) & Net Benefit (Birr/ha) & DominanceAnalysis & Marginal Rate of Return \\
\hline $30 \times 80$ & 4750 & 36481.67 & & \\
\hline $30 \times 60$ & 4840 & 17312 & $\mathrm{D}$ & \\
\hline $25 \times 60$ & 4900 & 25578.54 & $\mathrm{D}$ & \\
\hline $30 \times 100$ & 5450 & 29735.82 & $\mathrm{D}$ & \\
\hline $25 \times 80$ & 5600 & 33652.83 & $\mathrm{D}$ & \\
\hline $20 \times 60$ & 5700 & 22348.69 & $\mathrm{D}$ & \\
\hline $30 \times 120$ & 6050 & 21550.51 & $\mathrm{D}$ & \\
\hline $25 \times 100$ & 6300 & 35188.88 & $\mathrm{D}$ & \\
\hline $20 \times 80$ & 6400 & 39949.35 & & 210.16 \\
\hline $25 \times 120$ & 6900 & 20590.06 & $\mathrm{D}$ & \\
\hline $20 \times 100$ & 7100 & 36308.07 & $\mathrm{D}$ & \\
\hline $20 \times 120$ & 7700 & 19837.16 & $\mathrm{D}$ & \\
\hline
\end{tabular}

Cost of seed 20 Birr kg ${ }^{-1}$; Planting Cost Birr 50 per person per day; Sale price of rice grain Birr $15 \mathrm{~kg}^{-1}$; Sale price of rice straw $0.5 \mathrm{Birr}_{\mathrm{kg}}{ }^{-1}$

\section{Conclusion and Recommendations}

Rice is one of the most important food crop and a major food grain for more than a third of the world population. Ethiopian has a great potential for rice production because of its favorable environmental condition. Rice is highly sensitive to poor agronomic practices. Generating reliable information on agronomic management practices such as appropriate seed rate and row spacing are quite important to come up with profitable and sustainable upland rice production and productivity. Seed rate and row spacing areessential agronomic practices as it is a major management variable used in matching crop requirements to the environmental offer of resources. Metema is one of the production areas of upland rice. The experiment was carried out at two location of Metema district, North Gondar of Ethiopia, during, 2017 main cropping season.

A field experiment was conducted to assess the effect of seed rate and row spacing on yield components and yield of rice under rain fed. The combinations of four levels of seed 
rate $(60,80,100$ and 120$)$ and three levels of row spacing $(20,25$ and $30 \mathrm{~cm})$ were used as a treatment. The experiment was laid out in RCBD with factorial arrangement and replicated three times. The relevant data collected were subjected to analysis of variance using SAS software and significant treatment means were compared using least significant difference (LSD) test at 5\% probability level. The combine main effect of seed rate was highly significantly on days to heading, days to maturity, plant height, number of tiller per meter row length, panicle length, and number of filled grain per panicle, harvest index, biomass yield, and thousand seed weight. Seed rate of $80 \mathrm{~kg} \mathrm{ha}^{-1}$ was recorded significantly longest panicle length $(25.36 \mathrm{~cm})$ but statistically not significantly different on seed rate $100 \mathrm{~kg}$ ha 1 , highest number of filled grain per panicle (122.8) and highest harvest index (53.58). Whereas the seed rate of 120 $\mathrm{kg} \mathrm{ha}^{-1}$ showed significantly shortest panicle length (19.04 $\mathrm{cm})$, lowest number of filled grain per panicle (77.47) and harvest index (28.49).

The main combine effect of row spacing was also significantly on days to heading, and number of filled grain per panicle. The highest row spacing of $20 \mathrm{~cm}$ gave significantly highest number of filled grain per panicle (106.38). But row spacing not significance difference with days to $50 \%$ emergency, panicle length, number of unfilled grain per panicle and biomass yield. Days to $50 \%$ emergency and unfilled grain per panicle was not significantly affected by main effect of seed rate and row spacing. The interaction of seed rate and row spacing had a highly significant effect on days to heading, days to maturity, number of total tiller per $1 \mathrm{~m}$ row length, biomass yield, thousand seed weight and grain yield of upland rice variety. The longest days to physiological maturity (108.33 days) was recorded at $60 \mathrm{~kg} \mathrm{ha}^{-1}$ and $30 \mathrm{~cm}$ while the shortest days to maturity (92 days) was recorded at $100 \mathrm{~kg}$ $\mathrm{ha}^{-1}$ of seed rate and $20 \mathrm{~cm}$ of row spacing which had not significant difference with days to maturity found in response to the interaction of $\left(120 \mathrm{~kg} \mathrm{ha}^{-1}\right.$ and $\left.20 \mathrm{~cm}\right),(120$ $\mathrm{kg} \mathrm{ha}^{-1}$ and $\left.25 \mathrm{~cm}\right)$ and $\left(120 \mathrm{~kg} \mathrm{ha}^{-1}\right.$ and $\left.30 \mathrm{~cm}\right)$ of seed rate and row spacing respectively. The highest (7.73) total number of tiller per meter row length was found in $80 \mathrm{~kg}$ $\mathrm{ha}^{-1}$ and $20 \mathrm{~cm}$ seed rate and row spacing, respectively but the lowest (4.67) total number of tiller per meter row length was recorded at $120 \mathrm{~kg} \mathrm{ha}^{-1}$ of seed rate and $20 \mathrm{~cm}$ of row spacing. The significant highest biomass yield $\left(8110 \mathrm{~kg} \mathrm{ha}^{-1}\right)$ was recorded on seed rate $120 \mathrm{~kg} \mathrm{ha}^{-1}$ but statistically not significantly different on seed rate $100 \mathrm{~kg} \mathrm{ha}^{-1}$ while the lowest $\left(5710 \mathrm{~kg} \mathrm{ha}^{-1}\right)$ was recorded on seed rate of $60 \mathrm{~kg} \mathrm{ha}^{-}$ ${ }^{1}$. The interaction of seed rate and row spacing had highly significant effect on thousand seed weight of upland rice. The highest thousand seed weight $(27.3 \mathrm{~g})$ was obtained from interaction of $80 \mathrm{~kg} \mathrm{ha}^{-1}$ seed rate and $30 \mathrm{~cm}$ row spacing but not significance with $80 \mathrm{~kg} \mathrm{ha}^{-1}$ by $20 \mathrm{~cm}$ row spacing. While the lowest thousand seed weight $(17 \mathrm{~g})$ was obtained at $120 \mathrm{~kg} \mathrm{ha}^{-1}$ and $25 \mathrm{~cm}$ seed rate and row spacing respectively. The interaction of seed rate and row spacing had a significant effect on plant height of upland rice. The highest plant height $(115.67 \mathrm{~cm})$ was obtained from interaction of $120 \mathrm{~kg} \mathrm{ha}^{-1}$ seed rate and $30 \mathrm{~cm}$ row spacing. While the lowest plant height $(81 \mathrm{~cm})$ was obtained at $60 \mathrm{~kg}$ $\mathrm{ha}^{-1}$ and $20 \mathrm{~cm}$ seed rate and row spacing respectively.

The interaction effect of the two factors was highly significant on grain yield. The interactions of $80 \mathrm{~kg} \mathrm{ha}^{-1}$ seed rate and $20 \mathrm{~cm}$ row spacing gave the highest grain yield $\left(4148.8 \mathrm{~kg} \mathrm{ha}^{-1}\right)$ which was statistically at not significance with the yield obtained with the interaction of $100 \mathrm{~kg} \mathrm{ha}^{-1}$ and $20 \mathrm{~cm}$ row spacing $\left(3864.3 \mathrm{~kg} \mathrm{ha}^{-1}\right)$. On the other hand, the lowest grain yield $\left(1826.4 \mathrm{~kg} \mathrm{ha}^{-1}\right)$ was recorded with the interaction of $60 \mathrm{~kg} \mathrm{ha}^{-1}$ seed rate and 30 $\mathrm{cm}$ row spacing. The study, in general, revealed that rice responded positively to seed rate and row spacing. Significant responses in grain yield and other parameters of rice were observed at levels of seed rates and row spacing. Thus, seed rate of $80 \mathrm{~kg} \mathrm{ha}^{-1}$ with $20 \mathrm{~cm}$ row spacing could be considered as a preliminary recommendation for the study area for better economic advantage and acceptable rice yields for the cultivation of upland rice variety under the rain fed in North Gondar at Afetet 1 and Afetet 2 of Metema districts and similar agro ecology. However, to reach at conclusive recommendation the experiment has to be repeated across different years.

\section{Conflict of Interest}

The authors declare that there is no conflict of interest

\section{Appendix}

Table A1. Mean square values of ANOVA for yield components of rice as influenced by seed rate and row spacing at Metema, 2017.

\begin{tabular}{lllllll}
\hline SOV & df & DE & DH & DM & PH & PL \\
\hline REP & 2 & $0.75^{\text {ns }}$ & $0.69^{\text {ns }}$ & $7.4^{\text {ns }}$ & $5.66^{\text {ns }}$ & $6.718^{\text {ns }}$ \\
SR & 3 & $2.768^{\text {ns }}$ & $516.33^{* *}$ & $237.805^{* *}$ & $545.467^{* *}$ & $83.01^{* *}$ \\
RS & 2 & $0.25^{\text {ns }}$ & $39.69^{*}$ & $115.11^{* *}$ & $342.45^{* *}$ & $8.43^{\text {ns }}$ \\
Site & 1 & $0.12^{\text {ns }}$ & $80^{*}$ & $120^{*}$ & $250^{*}$ & $35^{*}$ \\
SR*RS & 6 & $1.10^{\text {ns }}$ & $66.69^{* *}$ & $50.2^{* *}$ & $36.67^{*}$ & $5.43^{\text {ns }}$ \\
Error & 22 & 1.08 & 11.42 & 5.4 & 12.698 & 2.75 \\
\hline
\end{tabular}

*: significant at $P<0.05$; **: highly significant difference at $P<0.01$; NS: non-significant at $P<0.05$; REP: replication; SR: seed rate; RS: row spacing; SOV: source of variation; df: degree of freedom; DE: days to emergency; DH: days to heading; DM: days to maturity, plant height, panicle length 
Table A2. Mean square values of ANOVA for yield and yield components of upland rice as affected by seed rate and row spacing at Afetet 1 and Afetet 2 of Metema districts during, 2017.

\begin{tabular}{|c|c|c|c|c|c|c|c|c|}
\hline SOV & df & NT & NFG & NUFG & BY & GY & TSW & HI \\
\hline REP & 2 & $0.66^{\mathrm{ns}}$ & $344.20^{\mathrm{ns}}$ & $2.97^{\mathrm{ns}}$ & $285395.11^{\mathrm{ns}}$ & $109879.30^{\text {ns }}$ & $2.32^{\mathrm{ns}}$ & $20.19^{\mathrm{ns}}$ \\
\hline SR & 3 & $4.32 * *$ & $4295.9 * *$ & $3.51^{\mathrm{ns}}$ & $10195563.25^{* *}$ & $5446853.4 * *$ & $78.67 * *$ & $992.6^{* *}$ \\
\hline RS & 2 & $7.16^{* *}$ & $677.167 *$ & $0.92^{\mathrm{ns}}$ & $499773.87^{\mathrm{ns}}$ & $760624.25 * *$ & $12.78 * *$ & $243.3 * *$ \\
\hline Site & 1 & $3.2 * *$ & $540 *$ & $1.6 \mathrm{~ns}$ & $66126704 *$ & $469432.7 \mathrm{~ns}$ & $34.8 * *$ & $587^{*}$ \\
\hline $\mathrm{SR} * \mathrm{RS}$ & 6 & $2.92^{* *}$ & $209.91^{\mathrm{ns}}$ & $4.278^{\mathrm{ns}}$ & $719991.04^{* *}$ & $234287.94 * *$ & $10.997 * *$ & $21.77^{\mathrm{ns}}$ \\
\hline Error & 22 & 1 & 149.8 & 3.06 & 193559.33 & 48242.98 & 2.656 & 17.37 \\
\hline
\end{tabular}

*: significant at $\mathrm{P}<0.05$; **: highly significant difference at $\mathrm{P}<0.01$; NS: non-significant; REP: replication; SR: seed rate; RS: row spacing; SOV: source of variation; df: degree of freedom; NTP: number of tiller per meter row length; NFG: number of filled grain per panicle; NUFG: number of unfilled grain per panicle; BY: biomass yield; GY: grain yield; TSW: thousand seed weight; HI: harvest index.

Journal of Agronomy 79: 864-869.

\section{References}

[1] Africa Rice Center. 2010. Improving Access toRice Seed and Building a Rice Data System forSubSaharan Africa (Japan Emergency Project). FinalReport of the Japan Emergency Project, Cotonou, Benin.

[2] Alam, M. S., Baki, M. A., Sultana, M. S., Ali, K. J. and Islam, M. S. 2012. Effect of variety, spacing and number of seedlings per hill on the yield potentials of transplant Aman rice. International Journal of Agriculture and Agricultural Research 2: 10-15.

[3] Ali, A., Abou, K., ELkhoby, W. and Okasha, E. M. 2014. Effect of sowing dates and seed rates on some rice cultivars. Filed Crops, Research institute, Rice Research and Training Center, ARC, Egypt. Water Relation and Field Irrigation Department, National Research Center, Egypt. African Journal of Agricultural Research 9 (2): 196-201.

[4] Ali, M. Abouzar, B., and Hashem. A. 2011. Effect of different levels of nitrogen and plant spacing on yield, yield components and physiological indices in high-yield rice (number 843), American-Eurasian Journal Agricultural and Environment Science 10 (5): 893-900.

[5] Ali, M. A, Ali, L., Sattar, M. and Ali, M. 2010. Improvement in wheat (Triticum aestivum L.) yield by manipulating seed rate and row spacing in Vehari zone. Journal of Animal and Plant Sciences 20 (4): 225-230.

[6] Balasubramanian, V., Sie, M., Hijmans, R. J., \&Otsuka, K. 2007. Increasing rice production in sub-Saharan Africa: challenges and opportunities. Advances in agronomy 94: 55-133.

[7] Baloch, A., M. Soomro, M. Javed and M. Ahmed. 2002. Optimum plant density for high yield in rice (Oryza sativa L.). Asian Journal of Plant Science 1 (1): 25-27.

[8] Brady, N. C. and R. R. Weil. 2002. The Nature and Properties of Soils. 12th ed. Prentice Hall Inc. International (UK) London.

[9] Chen, C. K., Neill, K., Wichman, D., and Westcott, C. 2008. Hard Red Spring Wheat Response to Row Spacing, Seeding Rate and Nitrogen. Agronomy Journal 100: 1296-1302.

[10] CIMMYT (International maize and wheat improvement center). 1988. From Agronomic Data to Farmer Recommendations: An Economics Training Manual. Completely revised edition, Mexico, DF.

[11] Counce, P. A. 1987. Asymptotic and parabolic yield and linear nutrient content responses to rice population density. Pakistan
[12] CSA (Central Statistical Agency). 2018. Agricultural sample survey: area and production of major crops, Meher season. Vol. I. Addis Ababa, Ethiopia.

[13] Dawit Alemu. 2015. Rice in Ethiopia: Progress in production increase and success factors. 6th CARD General Meeting; Ethiopian Institute of Agricultural Research, 1-22.

[14] Delessa Angassa. 2007. Effect of sowing method and seeding rate on yield and yield components of rain fed rice (Oryza sativa $\mathrm{L}$.) varieties in woliso, south-west shoa zone of Oromia region. M. Sc. thesis, Haramaya University, 30-59.

[15] Dereje S/dingel. 2016. Effects of seed and nitrogen rates on yield and yield attributes of upland rice under irrigation at Gewane, Northeastern Ethiopia, MSc Thesis in Agronomy, Haramaya University, Ethiopia.

[16] FAO (Food and Agricultural Organization of the United Nations). 2016. Worldagriculture: Towards 2015/2030 FAO perspective. Edited by Jelle Bruinsma, Earthscan Publications Ltd, London.

[17] Frizzell, D. L., C. E. Wilson, Jr., R. J. Norman, N. A Slaton, AL. Richards, and S. K. Runsick. 2006. Influence of row spacing and seeding rate on rice grain yield. University of Arkansas Agricultural Experiment Station Research Series 540: 270-275. Fayetteville, Arkanas.

[18] Ghansham, P. and Surjit, S. 2006. Effect of Seed Rate, Spacing and Herbicide Use on Weed Management in Direct Seeded Upland Rice (Oryza sativa L.). Department of Agronomy, PAU Ludhiana-141 004, Punjab, Indian journal of weed science 40 (1 \& 2): 11-15.

[19] Gorgy, N. 2010. Effect of transplanting spacing and nitrogen levels on growth, yield and nitrogen use efficiency of some promising rice varieties. Journal of Agricultural Research Kafer El-Shiekh University 36 (2): 123-146.

[20] Gunri, S. K., and Choudhary A. . 2004. Effect of integrated nitrogen application and spacing on yield of rice (Oryza sativa) in foot-hills soils of West Bengal. Indian Journal of Agronomy 49 (4): 248-250.

[21] Hai-xin, Z., Xiao-xue, W., Zhen-hua, G., Xiao-qun H. and Hua-long, L. 2012. Effects of row spacing on canopy structure and yield in different plant type rice cultivars, Journal of Northeast Agricultural University 19 (4): 11-19.

[22] Hamid, E., Taj, F. H., Bakht, J., Shah, A. W. and Shad, A. A. 2002. Effect of different planting dates, seed rates and nitrogen levels on wheat. Asian Journal of Plant Science 1: 502-506. 
[23] Harris, K. D. and Vijayaragavan, R. 2013. Optimum Seed Rate for Maximum yield in Rice (Oryza sativa L.). Research Journal of Agriculture and Forestry Sciences 3 (11), 1-5.

[24] Hiltbrunner, J., Streit, B., Liedgens, M. 2007. Are seeding densities an opportunity to increase grain yield of winter wheat in a living mulch of white clover? Field crop research. $102,163-171$.

[25] Hu, W. H., Qi, Y. J., Sun, M. C. and Guan, S. Y. 2000. Photosynthetic characters of sparsely populated rice. Journal of Jilin Agricultural University 22: 11-4.

[26] Hussain, M., Mehmood, Z., Khan, M. B., Farooq, S., Lee D. J. and Farooq, M. 2012. Narrow Row Spacing Ensures Higher Productivity of Low Tillering Wheat Cultivars. International Journal of Agriculture and Biology 14: 413-418.

[27] IPMS (improving productivity and market success) of Ethiopian farmer's project. 2005. Metema.

[28] IRRI (International Rice Research Institute), 1997. Rice Production Manual: 95. UPLB, Los Banos, the Philippines.

[29] Kabir M. H, Saha A, Mollah I. U, Kabir M. S, Rahman. F. 2008. Effect of crop establishment methods and weed management practices on the productivity of boro rice in lowland ecosystem. International journal of biology research 5: $42-51$.

[30] Kandil, A. A., El-KALLA, S. E., Badawi, A. T. and El-Shayb, M. 2010. Effect of hill spacing, nitrogen levels and harvest date on rice productivity and grain quality. Crop Environment 1: $22-26$.

[31] Mahato, P., Gunri, S. K., Chanda, K. and Ghosh, M. 2007. Effect of varying levels of fertilizer and spacing on medium duration rice (Oryza sativa L.) in Tarai Zone of West Bengal. Karnataka Journal of Agricultural Science. 20 (2): 363-365.

[32] Manjappa G. U., and Shailaja H. 2014. Association analysis of drought and yield related traits in F2 population of Moroberekan/IR64 rice cross under aerobic condition, Int. J. Agric. Sci. Res., 4, 79-88.

[33] Melkie Tilahun. 2017. Effect of row spacing and nitrogen fertilizer levels on yield and yield components of upland rice varieties at Pawe, North Western Ethiopia. Doctoral dissertation, Haramaya University, Haramaya.

[34] Miah, M. H., M. A. Karim, M. S. Rahman, and M. S. Islam. 1990. Performance of Nigersail mutants under different row spacings. Bangladesh Journal of Training Development 3 (2): 31-34.

[35] Missa Demissie. 2013. Effects of seed and nitrogen fertilizer rates on yield, yield components and grain quality of malting barley (Hordeum vulgare L.) in the central highlands of Ethiopia. A thesis submitted to the college of agriculture and environmental.

[36] Mobasser, H. R., Tari, D. B., Vojdani, M., Abadi, R. S., \&Eftekhari, A. 2007. Effect of seedling age and planting space on yield and yield components of rice (Neda variety). Asian Journal of Plant Sciences 6 (2), 438-440.

[37] Mondal, M. M. A, M. I. K. Rana, M. H. Imam and J. Sultana. 2012. Determination of row spacing based on morphological characters in rice. International Journal of Sustainable Crop Production 7 (1): 34-37.
[38] NMSA. 2017. Climate data for Metema, Ethiopia. National Meteorological Service Agency of Ethiopia, Bahir Dar Branch Office, Ethiopia

[39] Nwokwu, G. N. 2015. Performance of Lowland Rice (Oryza sativa L) as Affected by Transplanting Age and Plant Spacing in Abakaliki, Nigeria. Journal of Biology, Agriculture and Healthcare 5 (9). 165-177.

[40] Oikeh, S. O., Nwilene, F. F., Angnbiade, T., Oladimeji, O., Ajai, O., Semon, M., Tsenematsu, H. and Samejima, H. (Eds.). 2008. Growing Upland Rice: A production hand book, African Rice Centre, Cotonou, Benin. 44.

[41] Rahel Tigabu and Fekadu Asfaw. 2016. Effects of Seed Rate and Row Spacing on Yieldand Yield Components of Bread Wheat (Triticum aestivum L.) in Dalbo Awtaru Woreda, Wolaita Zone, and Southern Ethiopia. Journal of Biology, Agriculture and Healthcare 6 (7): 2224-3208.

[42] Rajeev, R. 2007. System of rice intensification under deferent plant population and levels of Nitrogen. M.Sc. thesis of Tribhuvan University, Rampur, Chitwan, Nepal.

[43] Salahuddin, K., S. Chowhdury, S. Munira, M. Islam, and S. Parvin. 2009. Response of Nitrogen and Plant spacing of transplanted aman rice. Bangladesh Journal of Agricultural Research 34 (2): 279-285.

[44] Sewenet Ashebir. 2005. Effects of nitrogen and seed rates on grain yield, yield Components and nitrogen uptake of rain fed rice (Oryza sativa) in Fogera, south Gonder. M. Sc. Thesis Alemaya University, Ethiopia.

[45] Sharif, A., Elizabeth, H., Muhammad, S., Bhagirathi, S., Chauhanca, B. 2015. Growth, yield and nitrogen use efficiency of dry-seeded rice as influenced by nitrogen and seed rates in Bangladesh. Field Crops Research 186: 18-31.

[46] Sohel, M. A. T., Siddique, M. A. B. Asaduzzaman, M. Alam M. N. and Karim, M. M. 2009. March varietal performance of transplanted aman rice under different hill densities. Bangladesh Journal Agricultural Research 34 (1): 33-39.

[47] Sokat Yiech. 2006. Nitrogen Uptake and Yield Response of Rain fed Rice (Oryza Sativa L.) Varieties to Fertilizer N on Luvisols of Gambella Region. M. Sc. Thesis, Haramaya University, Ethiopia.

[48] Sreepada, H. and Vijayalaxmi, H. 2013. Assessment of global rice production and export opportunity for economic development in Ethiopia. International Journal of Science and research (IJSR) India Online ISSN: 2319-7064.

[49] Sultana, M. R., Rahman, M. M. and Rahman, M. H. 2012. Effect of row and hill spacing on the yield performance of boro rice (cv. BRRI dhan45) under aerobic system of cultivation. Bangladesh Journal of Bangladesh Agricultural University 10 (1): 39-42.

[50] Tekle Yoseph and Wedajo Gebre. 2013. Determination of Optimum Seed Rate for Productivity of Rice (Oryza Sativa L.), at Woito, Southern Ethiopia. Agriculture, Forestry and Fisheries. 3 (3), 2014. 199-202.

[51] Uddin, M. J., Ahmed, S. and Hasan, M. M. 2010. Effect of spacing on morphology and yield response of different. Aman rice cultivars under coastal high land ecosystem. Indian Journal Agricultural Research 44 (4): 251-258. 
[52] WARDA (West African Rice Development Association). 2007. African Rice Initiative and NERICAdissemination. Cotonou, Benin.

[53] WARDA. 2008. NERICA®: the New Rice for Africa- a Compendium. EA Somado, RG Guei and SO Keya (eds.). Cotonou, Benin: Africa Rice Center (WARDA); Rome, Italy: FAO; Tokyo, Japan: Sasakawa Africa Association. 210.

[54] Worku Awdie. 2008. Effects of nitrogen and seed rates on yield and yield components of bread wheat (Triticum aestivum L.) in Yelmana Densa district, northwestern Ethiopia. M.Sc. Thesis. The School of Graduate Studies of Haramaya University. Harar, Ethiopia.

[55] Yordanos Ameyu. 2013. Influence of row spacing and nitrogen rates on yield and yield components of direct-sown irrigated rice at Gode, south-eastern Ethiopia. M.Sc thesis in Agronomy, Haramaya University, Haramaya. 